\title{
气候变化背景下中国风暴潮灾害风险及 适应对策研究进展
}

\author{
冯爱青 ${ }^{1,2}$, 高江波 ${ }^{1}$, 吴绍洪 ${ }^{1 *}$, 刘燕华 ${ }^{1,3}$,何霄嘉 ${ }^{4}$ \\ (1. 中国科学院地理科学与资源研究所, 陆地表层格局与模拟重点实验室, 北京 $100101 ; 2$. 中国科学院大学, \\ 北京 100049; 3. 国务院参事室, 北京 100006; 4. 中国21 世纪议程管理中心,北京 100038)
}

\begin{abstract}
摘 要: 风暴潮是沿海地区在强烈的大气扰动条件下产生的异常增水现象, 并受海平面上升等因素的影响。中国风 暴潮灾害频繁, 其中尤以东南沿海地区发生频率较高, 灾害损失严重。本文从风暴潮灾害的危险性、承灾体的易损 性、综合风险区划 3 个方面系统总结风暴潮灾害的研究进展及存在的主要问题; 并以风暴潮灾情特征及风险评估 为基础, 探讨气候变化对风暴潮灾害风险的影响及其适应对策。气候变化引起的海平面上升将影响风暴潮的趋 势、周期及风险区域, 因而亟待开展结合海平面上升等因素的综合风险评估。充分考虑气候变化背景下沿海地区 自然条件变化及社会经济发展状况, 注重短期与长期相结合, 完善风险评估体系。为适度、有序的适应气候变化下 风暴潮灾害风险, 中国在应急预警机制、工程防御及政策法规等适应能力建设方面不断完善, 以提高风暴潮灾害的 防灾减灾能力。
\end{abstract}

关 键 词:气候变化; 风暴潮灾害; 灾情; 风险; 适应; 中国

\section{1 引言}

20 世纪 90 年代以来, 全球气候变暖现象日益 突出, 风暴潮、台风、暴雨及洪水等自然灾害不断加 剧, 极端灾害事件频发(张利平等, 2011; Trenberth et al, 2015), 气候变化的风险已经引起人们的关注 (IPCC, 2014)。沿海地区是气候变化的敏感区域(蔡 榕硕等, 2014), 极易遭受风暴潮灾害的影响。风暴 潮是在强烈的大气扰动条件下 (如强风、气压骤变) 产生的异常增水的现象, 引起风暴潮的天气系统主 要有热带气旋、温带气旋及爆发性气旋等(冯士筰, 1982)。风暴潮灾害通常是指由异常的风暴增水与 其影响因素(如天文大潮、近岸浪、涌等)耦合产生的 高潮位导致人员伤亡和财产损失的灾害。其灾害
程度的大小主要受致灾因子危险性及承灾体的易 损性共同决定。致灾因子危险性表现为高潮位及 其发生频率大小; 易损性则是暴露于灾害下的承灾 体的损失程度。然而, 气候变化引起的海平面上升 也是风暴潮灾害的重要影响因素。当前研究对风 暴潮灾害的危险性重点关注的是风暴增水及近岸 浪、涌引起的高潮位, 易损性的评估也不够充分。 因此, 本文在综述风暴潮灾害的特征及其风险基础 上, 深人探讨气候变化下风暴潮灾害风险的发展趋 势及其适应措施。

\section{2 中国风暴潮灾情及分布格局}

中国是西太平洋海岸线最长的国家, 沿海地区

收稿日期: 2016-05; 修订日期: 2016-10。

基金项目: 国家科技支撑计划项目(2013BAK05B04); 中国清洁发展机制基金赠款项目(2013034) [Foundation: National Science and Technology Support Program, No.2013BAK05B04; Clean Development Mechanism Funding Projects of China, No.2013034]。

作者简介:冯爱青(1988-),女,山东聊城人,博士生,主要研究方向为气候变化的风险与适应,E-mail: fengaq.14b@igsnrr.ac.cn。 通讯作者: 吴绍洪(1961-), 男,广东潮州人,研究员, 主要研究方向为气候变化与综合自然地理学,E-mail: wush@igsnrr.ac.cn。 1419. [Feng A Q, Gao J B, Wu S H, et al. 2016. A review of storm surge disaster risk research and adaptation in China under climate change[J]. Progress in Geography, 35(11): 1411-1419.]. DOI: 10.18306/dlkxjz.2016.11.011 
城市化及社会经济快速发展, 人口与社会财富聚集 程度位居全球前列(McGranahan et al, 2007)。海岸 纵跨温、热两带, 渤海、黄海沿岸春、秋季节易引发 温带风暴潮, 而东南沿海地区夏、秋季节极易遭受 台风风暴潮, 灾害发生频繁(叶琳等, 2002)。风暴潮 的异常增水常常造成堤防摧损、油田淹没、住宅毁 坏、农业生产受阻等严重后果, 导致重大的经济损 失和人员伤亡。根据中国海洋灾害公报灾情统计: 2005-2015 年中国风暴潮过程累计 200 多次, 直接经 济损失高达 1500 多亿元; 其中, 单次直接经济损失 超过 10 亿元的风暴潮灾害多达 34 次, 直接经济损 失总计 1370 多亿元, 约占所有风暴潮灾害总损失的 90\%; 而“1409 威马逊”“1319天兔” “0814黑格比”及 “0518 达维”等特大风暴潮灾害则是由于风暴增水 适逢天文大潮或与近岸浪的共同影响, 单次直接经 济损失约为 80 120亿元。

据 1949-2015 年历史调查数据统计(图 1)(数据 源自于: Shi et al, 2015; 国家海洋局, 2015, 2016), 中 国风暴潮灾害整体呈北部沿海地区较弱、东南沿海 地区显著较强的格局。近 50 年来, 东南部沿海地区 风暴潮灾害的发生频率较高, 受灾人数较多, 直接 经济损失十分严重, 灾害危险性及受灾程度显著高 于北部海岸。尤以福建、广东 2 省风暴潮发生累计 频次最多, 近几年登陆较为频繁; 山东、浙江、福建、 广东、海南遭受风暴潮灾害的人员伤亡较为严重, 其中浙江遭受风暴潮灾害的累计伤亡人数高达
1962 人, 浙江、福建、广东 3 省的年平均直接经济损 失达 37 47 亿元。长时间序列的灾情统计结果表 明, 中国沿海地区风暴潮灾害程度严重且区域差异 显著。

\section{3 风暴潮灾害的风险评估}

风暴潮灾情统计仅能反映特定区域历史灾害 的实际发生情况及产生的影响, 当前的风险评估强 调危险性、暴露度及脆弱性等内涵属性。研究工作 主要集中于风暴潮灾害的危险性、承灾体的易损性 及风险区划 3 个方面。

\section{1 风暴潮灾害的危险性}

风暴潮灾害的危险性是风险评估的重要组成 部分, 其危险性评估方法主要包括: 风暴增水重现 期的拟合、基于过程的情景数值模拟及可能最大风 暴潮的计算。

风暴潮的重现期研究是评价风暴潮灾害危险 性的重要因素之一, 可实现对其危险性程度的长期 预估分析。风暴潮重现期的估计作为海岸工程设 计参数的参考依据, 是工程建设和灾害防护综合评 估的重要环节。概率统计分析方法主要包括:P-III 曲线、Fisher/Gumbel 分布、韦伯分布、柯西分布、广 义极值分布、帕累托分布、对数正态分布、指数分布 等参数模型。计算潮位或浪高等的典型重现期,中 国海堤工程设计一般推荐 Gumbel分布或P-III 型分

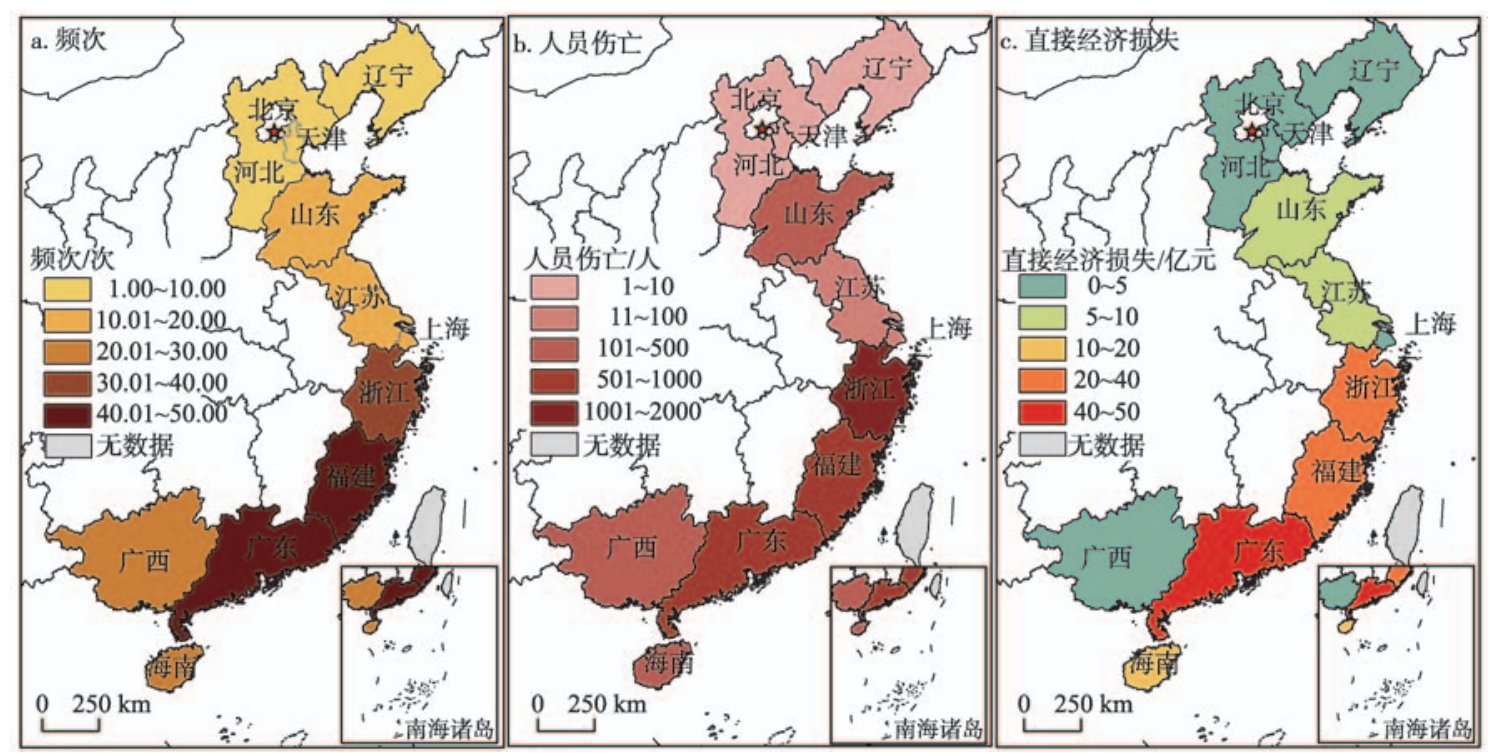

图 1 1949-2015 年中国沿海地区风暴潮灾情分布格局

Fig.1 China's coastal storm surge disasters and impacts, 1949-2015 
布(中华人民共和国交通部, 2000)。对潮位过程的 研究表明, 高潮位不仅与台风的特性有关, 还与天 文潮位等方面密切相关(邰佳爱等, 2009), 可通过联 合概率(Copula)方法构建风暴增水、海浪及天文潮 等多要素的累积概率分布(董胜等, 2005)进行预测 预报。基于风暴潮发生过程的数值模拟方法主要 通过台风气压场、风场等参数模拟风暴潮增水效 果, 克服了经验统计方法中历史样本量的限制 (黄 金池, 2002; 张百超等, 2014)。风暴潮数值模拟最 初用于风暴潮预报技术, 主要的数值模式有: 美国 的 SLOSH、英国的 SE、澳大利亚的 GCOM2D/3D、 荷兰的 DSCM 及 DELFT3D 、丹麦的 MIKE21 及加 勒比海地区的 TAOS 模式。美国联邦应急管理署 (FEMA)开展了大量沿海地区的风暴潮危险性评估 工作, 其研发的 HAZUS 模型被很多研究机构及国 家部门采用(FEMA, 2015)。在工程设计领域中, 对 重点防护工程设施(如核电站、石油钻井平台等)采 用可能最大风暴潮(PMSS)的设计标准: 即通过各等 级热带气旋参数之间的定量关系, 建立各参数设定 及路径合成的方法, 构建最优热带气旋计算可能最 大风暴潮(李颖等, 2014)。吴玮等(2012)模拟了风 暴增水叠加当地天文大潮所产生的风暴潮灾害, 二 者叠加将会造成大面积的漫堤现象, 淹没区域增 大。傅赐福等(2015)构建了非结构高分辨率的潮汐 一洪水耦合漫滩数值模型模拟水位变化及其相互 作用。鉴于历史资料时间序列的不足, 现有研究尝 试通过资料同化方法提高模拟潮位的准确度(李涛 等, 2015)。

风暴潮重现期的研究可以预估分析长期风暴 潮灾害的危险性, 但此方法因受历史样本量的限制 且不涉及风暴潮的形成过程, 具有一定的区域性。 数值模拟虽然克服了重现期方法的局限性, 但是仅 限于预测风暴潮个例, 不能预测风暴潮危险性的长 期趋势。因此, 应结合风暴潮重现期和数值模拟, 并加强可能最大风暴潮的预估, 提升风暴潮危险性 的短期和长期评估效果。

\section{2 风暴潮灾害承灾体的易损性}

承灾体的易损性包括暴露度和脆弱性。暴露 度即风暴潮灾害的影响范围, 脆弱性反映了暴露的 承灾体受风暴潮灾害的影响程度, 与沿海地区的自 然环境承载力、人口分布及社会经济状况密切相 关。脆弱性分析将灾害与风险紧密联系起来, 主要 方法有: 历史灾情方法、脆弱性曲线法、综合指数法 及图层叠置法等, 其中脆弱性曲线法和综合指数法
的研究和应用较为广泛。

风暴潮灾害脆弱性曲线的构建是评估易损性 的重要方法,主要基于灾情数据(包括历史文献、灾 害数据库及保险数据等)、系统调查及已有脆弱性 曲线的修正(周瑶等, 2012)。美国陆军工程师兵团 (USACE)和联邦应急管理署(FEMA)等机构收集了 大量风暴潮灾害的灾情数据并构建了较为完善的 脆弱性曲线(USACE, 2003; FEMA, 2015)。Jonkman 等(2008)基于美国、英国、日本、荷兰等国家的 灾情数据, 建立了风暴潮灾害人口脆弱性模型, 用 于人口伤亡的灾害评估。尹占娥等(2012)构建了农 作物、建筑、室内财产、道路等承灾体受风暴潮在内 的多种自然致灾因子的脆弱性特征。为优化脆弱 性曲线的构建, 现有研究正逐步针对具体灾后承灾 体的损失展开问卷调查。例如, 在住房损失方面, 对不同室内财产、室内装修及房屋结构条件的房屋 脆弱性完善了损失率的研究(曹诗嘉等, 2016)。

通过构建指标体系、采用综合指数等方法, 可 以有效地评估风暴潮灾害的自然脆弱性及社会脆 弱性(石先武等, 2016)。基于1990-2009年中国风暴 潮历史灾情数据, 构建了风暴潮灾害的自然脆弱性 评估指数(SSVI), 研究发现沿海省区 2005-2009年 的自然脆弱性较强, 受灾人口、农作物、水产养殖及 损毁的房屋对脆弱性的贡献最大 ( 谭丽荣等, 2011)。通过指标体系和主成分分析方法研究表明： 中国沿海绝大部分地市社会脆弱性处于中等脆弱 性水平, 东南沿海(广东、广西、海南)地区社会脆弱 性较高; 而上海、广州、天津和深圳等地具有很强的 灾害吸收力和恢复力, 脆弱性水平较低(谭丽荣, 2012)。为分类评估风暴潮灾害承灾体的易损性, 从社会经济、生态环境、土地利用和承灾能力等方 面初步建立了易损性评价指标体系(李阔等, 2011; Xu et al, 2016), 并对风暴潮灾害造成的区域生态环 境经济损失进行评估(于文金等, 2009)。中国东部 沿海地区各土地利用类型中, 公共设施和工业仓储 用地类型在不同重现期的风暴潮位下淹没损失值 较大(谢翠娜, 2010)。中国海岸的珠江三角洲、长江 三角洲、黄河三角洲及浙北、苏北、莱州湾、渤海湾、 辽东湾地区脆弱性较为显著(王康发生, 2010)。

易损性的研究具有很强的区域性且承灾体多 样化, 因此承灾体的易损性评估是风暴潮灾害风险 评估的难点。目前, 还未形成统一的评价指标体 系, 易损因子的选择和赋权亦具有很大的主观性。 为加强易损性的定量化研究, 优化脆弱性曲线的构 
建并完善易损性评价体系是未来风暴潮研究的 关键。

\section{3 风暴潮灾害的风险区划}

关于风暴潮灾害的风险区划, 国家海洋局与多 部门合作编制了《风暴潮风险评估和区划技术导 则》, 并与中国海洋灾害重点防御区划工作相结合, 逐步开展国家、省、市、县尺度的风暴潮灾害风险评 估和区划试点工作, 为中国海洋灾害的重点防御初 步区划提供了技术规范。

已有研究中, 史培军(2011)结合风暴潮灾害的 危险性与承灾体的脆弱性绘制了中国沿海风暴潮 灾害风险等级图。郜志超等(2012)与傅赐福等 (2013)根据沿海区域的地理、水文、社会经济等特 点, 构建风暴潮灾害风险评价模型, 对风暴潮灾害 危险度、易损性及防灾减灾能力进行分析, 最后绘 制出高分辨率的风暴潮灾害风险区划图。基于不 同评价指标的风暴潮风险区划结果有所差异。例 如, 以经济损失值和经济损失程度为例, 根据风暴 潮灾害可能产生的经济损失总值差异将中国沿海 地区分为高、较高、中、低 4 级经济风险区, 其中, 福 建、广东、浙江及上海风暴潮灾害经济风险突出, 而 天津、江苏和河北经济风险较低(王晓玲, 2010); 按 经济损失程度将沿海省市划分为 3 个区域, 其中上 海(第 1 区) 风暴潮经济损失风险最小, 海南、福建、 浙江、广东 4 省(第 3 区) 风险最大(赵领娣等, 2011)。 但迄今中国还未形成系统的风险区划评价指标体 系和区划方法。

\section{4 气候变化对风暴潮灾害风险的影响}

全球气候变暖背景下, 中国沿海地区高潮位呈 显著上升趋势, 风暴潮灾害的次数、强度和发生时 间跨度均有一定程度的增加(谢丽等, 2010; 卢美, 2013)。气候变化引起的海平面上升被认为是引起 沿海水位增长的重要内在驱动力 (Karim et al, 2008)。研究表明, 由于全球气候变化促使过去百 年极端事件的频繁发生(Winsemius et al, 2016), 气 候变化将对未来海岸带风暴潮灾害风险产生一定 的影响。

(1) 气候变化将影响风暴潮未来的趋势及重现 周期。近几十年全球气候变化引起的海平面平均 上升速率加快(Kopp et al, 2013; Hay et al, 2015), 预 估 2100 年风暴潮强度将上升 $2 \%$ 11\%, 发生频率将
增加 6\% 34\% (Knutson et al, 2010)。据 1954-2012 年的潮位记录数据统计, 中国沿海极值水位的增长 速率达 2.0 14.1 mm/a(Feng et al, 2014), 受气候变化 的影响显著。 20 世纪 90 年代以来, 中国沿海大部 分港口 100 年一遇的设计高潮位已被实测潮位超过 (陈奇礼等, 1995)。早期研究表明:未来海平面上升 $0.3 \mathrm{~m}$, 广州黄埔港 100 年一遇风暴潮水位将降为 30 年一遇(黄镇国等, 2003); 而海平面上升 $0.5 \mathrm{~m}$, 天津 海岸和上海黄浦 100 年一遇高潮位降为 10 年一遇, 广州附近海岸则降为 20 年一遇(杨桂山等, 1995)。 近期研究指出: 由于海平面上升,至 2050 年, 100 年 一遇的极值水位的重现期将变为 10 30 年一遇; 至 2100 年, 1000 年一遇的极值水位重现期将缩短为 10 年一遇, 气候变化引起的海平面上升将显著缩短 极值水位的重现期(Wu et al, 2016)

(2) 气候变化将扩大沿海受灾区域并加重影响 程度。即使全球升温控制在 $2^{\circ} \mathrm{C}$ 以内, 全球海平面 上升高度仍超过 $1 \mathrm{~m}$ (Levermann et al, 2013; Dutton et al, 2015), 未来全球暴露于高淹没频率的城市及 三角洲淹没区域增加(Syvitski et al, 2009; Güneralp et al, 2015)。海岸带的淹没灾害对社会经济影响很 大,未来沿海地区更多的人口和资产将暴露于淹没 风险之下 (Mokrech et al, 2012; Hinkel et al, 2014; Alfieri et al, 2015)。中国 30\%以上的海岸带地区为 风暴潮灾害高脆弱性区域(Yin et al, 2012), 由于人 口趋海迁移现象严重, 处于淹没风险的人口数量将 是世界上最多的国家(Neumann et al, 2015)。通过 评估百年一遇重现期的淹没风险, 广州、深圳、天津 的风险程度位于全球前 20 位, 海平面上升将造成巨 大的损失(Hallegatte et al, 2013)。综合考虑海平面 上升、潮位及地壳垂直运动, 未来 30 年上海市局部 区域淹没深度可达 $3.0 \mathrm{~m}$ 以上,全市 $25 \%$ 的海塘和 防汛墙存在漫堤风险(Yin et al, 2011; 宋城城等, 2014)。预计到 2100 年山东沿渤海湾地区, 100 年一 遇风暴潮灾害的淹没范围将向内陆推进距离约为 240 800 m, 人口及社会经济将受到严重影响(龙飞 鸿等, 2015)。21世纪内, 海平面上升并伴随经济恶 化及生态破坏, 发展中国家沿海地区的数亿人口可 能流离失所(Dasgupta et al, 2009)。

综上所述, 气候变化将显著加剧未来风暴潮的 灾害程度, 其引起的海平面上升也会增加沿海地区 的风险。因此,加强气候变化下风暴潮灾害的极端 风险研究对海岸带的防灾减灾具有重要意义。 


\section{5 气候变化下风暴潮灾害风险的适应 对策}

随着全球气候变化的影响日益显著, 国内外对 气候变化的适应认识不断增强(巢清尘等, 2014; Magnan, 2016)。通过成本一效益计算分析表明, 由 于海平面上升造成的沿海地区淹没损失要远大于 适应的成本 (Hallegatte et al, 2011; Hinkel et al, 2014)。在中国风暴潮灾情特征及风险评估的基础 上,通过分析气候变化引起的海平面上升对风暴潮 灾害风险的影响,发现未来中国沿海地区风暴潮灾 害风险形势更加严峻。海岸带区域受气候变化的 影响突显,但目前中国的适应研究仅处于初步阶段 (吴绍洪等, 2014; 吴绍洪等, 2016), 为此, 迫切需要 加强沿海地区适应措施的研究。

围绕沿海地区加强适应气候变化的战略与防 御灾害风险的重点任务,中国正在发展和集成符合 中国国情的海岸带灾害适应技术框架(刘燕华等, 2013)。而针对气候变化下风暴潮灾害风险适应的 步骤主要包括: (1)定量化评估气候变化下风暴潮灾 害的风险是研究适应的前提, 提高国家、部门及民 众对未来风险的认识。(2定量分析沿海地区的抗 灾减灾能力。目前沿海地区减灾能力区域差异显 著, 上海、广州等地的减灾能力相对较强, 而其他地 区相对较弱。(3)科学设定减灾目标, 确定适应层 面、时效层面及程度的目标。减灾适应目标不仅要 考虑国家层面，还应制定区域层面目标。减灾时效 目标分为长期、中期及近期目标; 而减灾程度目标 应以适度适应为原则, 谨防过度适应及适应不足 (李阔等, 2016)。(4)综合风暴潮灾害的风险与当前 的减灾能力, 通过量化减灾能力的不足, 加强减灾 适应能力建设。

为适应气候变化下风暴潮灾害的风险, 中国在 预警应急响应、工程防御及政策法规等适应能力建 设方面不断加强。一是健全观测、预警机制。目 前, 中国已经初步形成立体海洋观测网和海洋观测 数据传输网, 现已建设由国家到县区的逐级预警预 报服务体系,搭建了较为完整的风暴潮灾害观测预 报网络,正在逐步完善和提高气候变化条件下的风 暴潮灾害预警能力(何霄嘉等, 2012); 同时,进一步 完善了风暴潮灾害应急预案体系和响应机制, 全面 提高沿海地区的防御灾害能力。二是建设海岸防 护工程,包括: (1)针对气候变化将加剧风暴潮灾害
的风险,对重点防护地区提高海堤等防御标准,沿 海地区大部分堤防都已经达到或接近 50 年一遇防 护标准,其中天津等沿海重点城市已建设成 100 年 一遇高标准防护堤坝, 而风险较大的上海市防护堤 由 100 年一遇提高到 1000 年一遇。2 建设生物护 岸工程等低成本高效益、无生态危害的可持续生态 防御措施, 可起到护滩、护堤和促淤等海岸防护作 用(Temmerman et al, 2013)。目前, 中国部分地区已 建有生态防洪防灾工程, 如上海、江苏及黄河三角 洲沿海的防护林及生态湿地等建设, 有效地减轻了 海岸的侵蚀并取得良好的效果。三是健全气候变 化适应的政策法规。中国海洋部门相继出台了《关 于海洋领域应对气候变化有关工作的意见》《海洋 灾害应急预案》等一系列方案(伅天宇, 2010), 制定 了较为科学合理的应对海洋灾害(包括风暴潮)的程 序与标准,进而为相关管理部门应对极端的海洋灾 害提供科学依据与参考。为改善海洋环境和加强 资源保护,并有效地遏制海洋资源过度开发,中国 在近年来陆续颁发及修订了相关法律法规(如《海 洋环境保护法》等)。但目前中国现有法律法规尚 不能满足长期适应气候变化的要求, 亟待进一步健 全相关法律法规体系。

\section{6 研究展望}

通过对中国风暴潮灾害特征及风险分析,结合 全球气候变化的影响, 实现风暴潮灾害风险定量化 综合评估及其有序适应, 是未来研究的主要方向。

(1) 风暴潮灾害风险评估应重视定量化与综合 性。当前, 对气候变化背景下风暴潮灾害的危险 性、暴露度及脆弱性的综合风险评估不足,未来以 风暴增水为主的单因素风险评估应转向多因素的 综合评估, 并将气候变化引起的海平面上升与风暴 潮、天文潮等因素结合,计算未来极值水位的重现 期。脆弱性曲线具有一定区域适用性, 应加强其系 统化构建。研究重现期变化与系统构建脆弱性曲 线是实现定量化综合风险评估要解决的关键科学 问题。

(2) 在综合风险评估的基础上,实现气候变化 下风暴潮灾害风险的有序适应。随着全球气候变 化和社会经济的发展,沿海地区的综合风险格局也 在逐渐改变,应甄别风暴潮灾害风险的敏感区和重 点区,提高适应措施的适用性和针对性。现阶段研 
究主要侧重于短期的风险评估与适应, 未来应注重 长期与短期相结合, 采取技术可行的适应措施, 兼 顾经济、社会、环境效益,达到适度适应,并尽量避 免过度适应与适应不足。

\section{参考文献(References)}

蔡榕硕, 齐庆华. 2014. 气候变化与全球海洋: 影响、适应和 脆弱性评估之解读 [J]. 气候变化研究进展, 10(3): 185190. [Cai R S, Qi Q H. 2014. Key points on impact assessment of climate change on the ocean and related adaptation from the IPCC Working Group II Fifth Assessment Report $[\mathrm{J}]$. Progressus Inquisitiones de Mutatione Climatis, 10 (3): 185-190.]

曹诗嘉, 方伟华, 谭骏. 2016. 基于海南省“威马逊”及“海鸥” 台风次生海岸洪水灾后问卷调查的室内财产脆弱性研 究[J]. 灾害学, 31(2): 188-195. [Cao S J, Fang W H, Tan J. 2016. Vulnerability of building contents to coastal flooding based on questionnaire survey in Hainan after Typhoon Rammasun and Kalmeagi[J]. Journal of Catastrophology, 31(2): 188-195.]

巢清尘, 刘昌义, 袁佳双. 2014. 气候变化影响和适应认知的 演进及对气候政策的影响 $[\mathrm{J}]$. 气候变化研究进展, 10(3): 167-174. [Chao Q C, Liu C Y, Yuan J S. 2014. The evolvement of impact and adaptation on climate change and their implications on climate policies[J]. Progressus Inquisitiones de Mutatione Climatis, 10(3): 167-174.]

陈奇礼, 陈特固. 1995. 海平面上升对中国沿海工程的潮位 和波高设计值的影响 [J]. 海洋工程, 13(1): 1-7. [Chen Q L, Chen T G. 1995. Influence of sea level rise on design values of wave and tide in China adjacent seas[J]. The Ocean Engineering, 13(1): 1-7.]

董胜, 郝小丽, 李锋, 等. 2005. 海岸地区致灾台风暴潮的长 期分布模式 $[J]$. 水科学进展, 16(1): 42-46. [Dong S, Hao X L, Li F, et al. 2005. Long term distribution of disastercaused typhoon storm surges in the coastal area[J]. Advances in Water Science, 16(1): 42-46.]

冯士筰. 1982. 风暴潮导论 [M]. 北京: 科学出版社. [Feng S Z. 1982. Fengbaochao daolun[M]. Beijing, China: Science Press.]

傅赐福, 董剑希, 刘秋兴, 等. 2015. 闽江感潮河段潮汐: 洪水 相互作用数值模拟 [J]. 海洋学报, 37(7): 15-21. [Fu C F, Dong J X, Liu Q X, et al. 2015. Flood-tide interaction numerical simulation in Minjiang River tidal reach[J]. Haiyang Xuebao, 37(7): 15-21.]

傅赐福, 于福江, 王培涛, 等. 2013. 滨海新区温带风暴潮灾 害风险评估研究 [J]. 海洋学报, 35(1): 55-62. [Fu C F, Yu F J, Wang P T, et al. 2013. A study on extra tropical storm surge disaster risk assessment at Binhai New Area[J]. Acta
Oceanologica Sinica, 35(1): 55-62.]

郜志超, 于沝, 丁照东. 2012. 基于 GIS 技术的台风风暴潮灾 害风险评估: 以台州市为例 [J]. 海洋环境科学, 31(3): 439-442, 447. [Gao Z C, Yu M, Ding Z D. 2012. Typhoon storm surge risk assessment based on GIS: A case study of Taizhou[J]. Marine Environmental Science, 31(3): 439442, 447.]

国家海洋局. 2015. 2014 年中国海洋灾害公报[R]. 北京: 国 家海洋局. [State Oceanic Administration of China. 2015. 2014nian Zhongguo haiyang zaihai gongbao[R]. Beijing, China: State Oceanic Administration of China.]

国家海洋局. 2016. 2015 年中国海洋灾害公报 [R]. 北京: 国 家海洋局. [State Oceanic Administration of China. 2016. 2015nian Zhongguo haiyang zaihai gongbao[R]. Beijing, China: State Oceanic Administration of China.]

何霄嘉, 张九天, 伅天宇, 等. 2012. 海平面上升对我国沿海 地区的影响及其适应对策 [J]. 海洋预报, 29(6): 84-91. [He X J, Zhang J T, Zhang T Y, et al. 2012. Study on the sea level rising in the China coast and its adaptation strategy[J]. Marine Forecasts, 29(6): 84-91.]

黄金池. 2002. 中国风暴潮灾害研究综述[J]. 水利发展研究, 2(12): 63-65. [Huang J C. 2002. Review of storm surge disaster research in China[J]. Water Resources Development Research, 2(12): 63-65.]

黄镇国, 张伟强, 陈奇礼, 等. 2003. 海平面上升对广东沿海 工程设计参数的影响 [J]. 地理科学, 23(1): 39-41. [Huang Z G, Zhang W Q, Chen Q L, et al. 2003. Impacts of sea level rise on design parameters of coastal engineering in Guangdong Province[J]. Scientia Geographica Sinica, 23 (1): 39-41.]

李阔, 何霄嘉, 许吟隆, 等. 2016. 中国适应气候变化技术分 类研究 $[\mathrm{J}]$. 中国人口・资源与环境, 26(2): 18-26. [Li K, He X J, Xu Y L, et al. 2016. Study on classification of adaptation technologies to climate change in China[J]. China Population, Resources and Environment, 26(2): 18-26.]

李阔, 李国胜. 2011. 广东沿海地区风暴潮易损性评估[J]. 热 带地理, 31(2): 153-158, 177. [Li K, Li G S. 2011. A storm surge vulnerability assessment for coastal Guangdong[J]. Tropical Geography, 31(2): 153-158, 177.]

李涛, 吴少华, 侯京明, 等. 2015. 资料同化在渤黄海风暴潮 重现期计算中的应用研究 [J]. 海洋通报, 34(6): 631-641. [Li T, Wu S H, Hou J M, et al. 2015. Study on the application of the data assimilation in the return period of storm surge in Bohai Sea and Yellow Sea[J]. Marine Science Bulletin, 34(6): 631-641.]

李颖, 方伟华, 林伟, 等. 2014. 可能最大风暴潮风险评估中 各等级热带气旋设定方法 [J]. 海洋科学, 38(4): 71-80. [Li Y, Fang W H, Lin W, et al. 2014. Parameterization of synthetic tropical cyclones at various scales for probable 
maximum storm surge risk modeling[J]. Marine Sciences, 38(4): 71-80.]

刘燕华, 钱风鬼, 王文涛, 等. 2013. 应对气候变化的适应技 术框架研究 $[\mathrm{J}]$. 中国人口・资源与环境, 23(5): 1-6. [Liu Y H, Qian F K, Wang W T, et al. 2013. Research of adaptive technology framework of addressing climate change [J]. China Population, Resources and Environment, 23(5): 1-6.]

龙飞鸿, 石学法, 罗新正. 2015. 海平面上升对山东沿渤海湾 地区百年一遇风暴潮淹没范围的影响预测 $[\mathrm{J}]$. 海洋环境 科学, 34(2): 211-216. [Long F H, Shi X F, Luo X Z. 2015. The impact prediction of sea level rise on the inundated area caused by 100-year recurrence-period storm surge of Shandong Province around Bohai Bay[J]. Marine Environmental Science, 34(2): 211-216.]

卢美. 2013. 浙江海岸台风风暴潮漫堤风险评估研究[D]. 杭 州: 浙江大学. [Lu M. 2013. Study on risk assessment of seawall overflowed by typhoon storm surge at Zhejiang coast[D]. Hangzhou, China: Zhejiang University.]

石先武, 国志兴, 张尧, 等. 2016. 风暴潮灾害脆弱性研究综 述 $[J]$. 地理科学进展, 35(7): 889-897. [Shi X W, Guo Z X, Zhang Y, et al. 2016. A review of research on vulnerability to storm surges[J]. Progress in Geography, 35(7): 889-897.] 史培军. 2011. 中国自然灾害风险地图集[J]. 北京: 科学出版 社. [Shi P J. 2011. Atlas of natural disaster risk of China [M]. Beijing, China: Science Press.]

宋城城, 李梦雅, 王军, 等. 2014. 基于复合情景的上海台风 风暴潮灾害危险性模拟及其空间应对 [J]. 地理科学进 展, 33(12): 1692-1703. [Song C C, Li M Y, Wang J, et al. 2014. Simulation of typhoon storm surge impacts in Shanghai based on storm surge scenarios and disaster prevention measures[J]. Progress in Geography, 33(12): 1692-1703.]

邰佳爱, 张长宽, 宋立荣. 2009. 强台风 0814(黑格比)和 9615 (莎莉)台风暴潮珠江口内超高潮位分析[J]. 海洋通报, 28 (6): 14-18. [Tai J A, Zhang C K, Song L R. 2009. Super high water levels due to intense typhoons 0814 (Hagupit) and 9615 (Sally) in the Peal River Estuary[J]. Marine Science Bulletin, 28(6): 14-18.]

谭丽荣. 2012. 中国沿海地区风暴潮灾害综合脆弱性评估 [D]. 上海: 华东师范大学. [Tan L R. 2012. Assessment on comprehensive vulnerability of storm surge disasters of China's coastal regions[D]. Shanghai, China: East China Normal University.]

谭丽荣, 陈珂, 王军, 等. 2011. 近 20 年来沿海地区风暴潮灾 害脆弱性评价[J]. 地理科学, 31(9): 1111-1117. [Tan L R, Chen K, Wang J, et al. 2011. Assessment on storm surge vulnerability of coastal regions during the past twenty years [J]. Scientia Geographica Sinica, 31(9): 1111-1117.] 王康发生. 2010. 海平面上升背景下中国沿海台风风暴潮脆
弱性评估[D]. 上海: 上海师范大学. [Wang K F S. 2010. Typhoon storm surge vulnerability analyses of China coastal area on the sea revel rise background[D]. Shanghai, China: Shanghai Normal University.]

王晓玲. 2010. 我国风暴潮灾害经济风险区划[D]. 青岛: 中国 海洋大学. [Wang X L. 2010. Regionalization of economic risk on storm surge disaster in China[D]. Qingdao, China: Ocean University of China.]

吴绍洪, 黄季焜, 刘燕华, 等. 2014. 气候变化对中国的影响 利弊 $[\mathrm{J}]$. 中国人口・资源与环境, 24(1): 7-13. [Wu S H, Huang J K, Liu Y H, et al. 2014. Pros and cons of climate change in China[J]. China Population, Resources and Environment, 24(1): 7-13.]

吴绍洪, 罗勇, 王浩, 等. 2016. 中国气候变化影响与适应: 态 势和展望 $[\mathrm{J}$ ]. 科学通报, 61(10): 1042-1054. [Wu S H, Luo Y, Wang H, et al. 2016. Climate change impacts and adaptation in China: Current situation and future prospect [J]. Chinese Science Bulletin, 61(10): 1042-1054.]

吴玮, 刘秋兴, 于福江, 等. 2012. 台州沿海地区台风风暴潮 淹没风险分析 [J]. 海洋预报, 29(2): 25-31. [Wu W, Liu Q $\mathrm{X}, \mathrm{Yu} \mathrm{F}$ J, et al. 2012. Inundation risk assessment of typhoon storm surge along Taizhou coastal areas[J]. Marine Forecasts, 29(2): 25-31.]

谢翠娜. 2010. 上海沿海地区台风风暴潮灾害情景模拟及风 险评估[D]. 上海: 华东师范大学. [Xie C N. 2010. Risk assessment and scenario simulation of storm surge in Shanghai coastal areas[D]. Shanghai, China: East China Normal University.]

谢丽, 张振克. 2010. 近 20 年中国沿海风暴潮强度、时空分布 与灾害损失 [J]. 海洋通报, 29(6): 690-696. [Xie L, Zhang Z K. 2010. Study on the relationship between intensity, spatial-temporal distribution of storm surges and disaster losses along the coast of China in past 20 years[J]. Marine Science Bulletin, 29(6): 690-696.]

杨桂山, 施雅风. 1995. 海平面上升对中国沿海重要工程设 施与城市发展的可能影响[J]. 地理学报, 50(4): 302-309. [Yang G S, Shi Y F. 1995. Possible impacts of sea level rise on major projects and urban development in the coastal areas in China[J]. Acta Geographica Sinica, 50(4): 302309.]

叶琳, 于福江. 2002. 我国风暴潮灾的长期变化与预测 [J]. 海 洋预报, 19(1): 89-96. [Ye L, Yu F J. 2002. The long-range change and forecast of storm surge disasters in China[J]. Marine Forecasts, 19(1): 89-96.]

尹占娥, 许世远. 2012. 城市自然灾害风险评估研究 [M]. 北 京: 科学出版社. [Yin Z E, Xu S Y. 2012. Study on risk assessment of urban natural hazards[M]. Beijing, China: Science Press.]

于文金, 吕海燕, 张朝林, 等. 2009. 江苏盐城海岸带风暴潮 
灾害经济评估方法研究 [J]. 生态经济, (7): 154-159. [Yu W J, Lv H Y, Zhang C L, et al. 2009. Research on economic method of assessment on Jiangsu Yancheng coastal storm surge disaster[J]. Ecological Economy, (7): 154-159.] 张百超, 董剑希, 吴少华. 2014. 利用风暴潮数值模式计算重 现期风暴潮的一种方法 [J]. 海洋预报, 31(4): 24-31. [Zhang B C, Dong J X, Wu S H. 2014. Computation of return period of storm surge based on numerical model[J]. Marine Forecasts, 31(4): 24-31.]

张利平, 杜鸿, 夏军, 等. 2011. 气候变化下极端水文事件的 研究进展 [J]. 地理科学进展, 30(11): 1370-1379. [Zhang L P, Du H, Xia J, et al. 2011. Progress in the study of extreme hydrologic events under climate change[J]. Progress in Geography, 30(11): 1370-1379.]

伅天宇. 2010. 我国海洋领域适应气候变化的政策与行动 [J]. 海洋预报, 27(4): 67-73. [Zhang T Y. 2010. Policies and actions for adaptation to climate change in China marine area[J]. Marine Forecasts, 27(4): 67-73.]

赵领娣, 陈明华. 2011. 中国东部沿海省市风暴潮经济损失 风险区划 [J]. 自然灾害学报, 20(5): 100-104. [Zhao L D, Chen M H. 2011. Risk zoning of economic loss caused by storm surge in coastal provinces and cities of China[J]. Journal of Natural Disasters, 20(5): 100-104.]

中华人民共和国交通部. 2000. JTJ 213-98 海港水文规范[S]. 北京: 人民交通出版社. [Ministry of Communications of the People's Republic of China. 2000. Code of hydrology for sea harbour[S]. Beijing, China: China Communications Press.]

周瑶, 王静爱. 2012. 自然灾害脆弱性曲线研究进展 [J]. 地球 科学进展, 27(4): 435-442. [Zhou Y, Wang J A. 2012. A review on development of vulnerability curve of natural disaster[J]. Advances in Earth Science, 27(4): 435-442.]

Alfieri L, Feyen L, Dottori F, et al. 2015. Ensemble flood risk assessment in Europe under high end climate scenarios[J]. Global Environmental Change, 35: 199-212.

Dasgupta S, Laplante B, Meisner C, et al. 2009. The impact of sea level rise on developing countries: A comparative analysis[J]. Climatic Change, 93(3-4): 379-388.

Dutton A, Carlson A E, Long A J, et al. 2015. Sea-level rise due to polar ice-sheet mass loss during past warm periods [J]. Science, 349: doi: 10.1126/science.aaa4019.

FEMA. 2015. HAZUS-MH flood model: Technical manual[Z/ OL]. 2015-02-29[2016-05-29]. https://www.fema.gov/media-library/assets/documents/24609?id=5120.

Feng X B, Tsimplis M N. 2014. Sea level extremes at the coasts of China[J]. Journal of Geophysical Research: Oceans, 119(3): 1593-1608.

Güneralp B, Güneralp İ, Liu Y. 2015. Changing global patterns of urban exposure to flood and drought hazards[J]. Global
Environmental Change, 31: 217-225.

Hallegatte S, Green C, Nicholls R J, et al. 2013. Future flood losses in major coastal cities[J]. Nature Climate Change, 3 (9): 802-806.

Hallegatte S, Ranger N, Mestre O, et al. 2011. Assessing climate change impacts, sea level rise and storm surge risk in port cities: A case study on Copenhagen[J]. Climatic Change, 104(1): 113-137.

Hay C C, Morrow E, Kopp R E, et al. 2015. Probabilistic reanalysis of twentieth-century sea-level rise[J]. Nature, 517: 481-484.

Hinkel J, Lincke D, Vafeidis A T, et al. 2014. Coastal flood damage and adaptation costs under 21 st century sea-level rise[J]. Proceedings of the National Academy of Sciences of the United States of America, 111(9): 3292-3297.

IPCC. 2014. Climate change 2014: Impacts, adaptation, and vulnerability. Part A: Global and sectoral aspects. Contribution of Working Group II to the Fifth Assessment Report of the Intergovernmental Panel on Climate Change[M]. Cambridge, UK \& New York: Cambridge University Press.

Jonkman S N, Vrijling J K. 2008. Loss of life due to floods[J]. Journal of Flood Risk Management, 1(1): 43-56.

Karim M F, Mimura N. 2008. Impacts of climate change and sea-level rise on cyclonic storm surge floods in Bangladesh [J]. Global Environmental Change, 18(3): 490-500.

Knutson T R, McBride J L, Chan J, et al. 2010. Tropical cyclones and climate change[J]. Nature Geoscience, 3(3): 157-163.

Kopp R E, Simons F J, Mitrovica J X, et al. 2013. A probabilistic assessment of sea level variations within the last interglacial stage[J]. Geophysical Journal International, 193(2): 711-716.

Levermann A, Clark P U, Marzeion B, et al. 2013. The multimillennial sea- level commitment of global warming[J]. Proceedings of the National Academy of Sciences of the United States of America, 110(34): 13745-13750.

Magnan A K. 2016. Climate change: Metrics needed to track adaptation[J]. Nature, 530: 160.

McGranahan G, Balk D, Anderson B. 2007. The rising tide: Assessing the risks of climate change and human settlements in low elevation coastal zones[J]. Environment and Urbanization, 19(1): 17-37.

Mokrech M, Nicholls R J, Dawson R J. 2012. Scenarios of future built environment for coastal risk assessment of climate change using a GIS-based multicriteria analysis[J]. Environment and Planning B: Planning and Design, 39(1): 120-136.

Neumann B, Vafeidis A T, Zimmermann J, et al. 2015. Future 
coastal population growth and exposure to sea-level rise and coastal flooding-A global assessment[J]. PLoS One, 10 (3): doi: 10.1371/journal.pone.0118571.

Shi X W, Liu S, Yang S N, et al. 2015. Spatial-temporal distribution of storm surge damage in the coastal areas of China [J]. Natural Hazards, 79(1): 237-247.

Syvitski J P M, Kettner A J, Overeem I, et al. 2009. Sinking deltas due to human activities[J]. Nature Geoscience, 2 (10): 681-686.

Temmerman S, Meire P, Bouma T J, et al. 2013. Ecosystembased coastal defence in the face of global change[J]. Nature, 504: 79-83.

Trenberth K E, Fasullo J T, Shepherd T G. 2015. Attribution of climate extreme events[J]. Nature Climate Change, 5(8): 725-730.

USACE. 2003. Economic guidance memorandum (EGM) 0401, generic depth- damage relationships for residential structures with basements, CECW- PG10[Z]. Washington DC: USACE.
Winsemius H C, Aerts J C J H, van Beek L P H, et al. 2016. Global drivers of future river flood risk[J]. Nature Climate Change, 6(4): 381-385.

Wu S H, Feng A Q, Gao J B, et al. 2016. Shortening the recurrence periods of extreme water levels under future sea-level rise[J]. Stochastic Environmental Research and Risk Assessment, doi: 10.1007/s00477-016-1327-2.

Xu L L, He Y R, Huang W, et al. 2016. A multi-dimensional integrated approach to assess flood risks on a coastal city, induced by sea-level rise and storm tides[J]. Environmental Research Letters, 11(1): 14001-14012.

Yin J, Yin Z E, Hu X M, et al. 2011. Multiple scenario analyses forecasting the confounding impacts of sea level rise and tides from storm induced coastal flooding in the city of Shanghai, China[J]. Environmental Earth Sciences, 63 (2): 407-414.

Yin J, Yin Z E, Wang J, et al. 2012. National assessment of coastal vulnerability to sea-level rise for the Chinese coast [J]. Journal of Coastal Conservation, 16(1): 123-133.

\title{
A review of storm surge disaster risk research and adaptation in China under climate change
}

\author{
FENG Aiqing $^{1,2}$, GAO Jiangbo ${ }^{1}$, WU Shaohong ${ }^{1 *}$, LIU Yanhua ${ }^{1,3}$, HE Xiaojia $^{4}$ \\ (1. Key Laboratory of Land Surface Pattern and Simulation, Institute of Geographic Sciences and Natural \\ Resources Research, CAS, Beijing 100101, China; 2. University of Chinese Academy of Sciences, Beijing \\ 100049, China; 3. Counselors' Office of the State Council, Beijing 100006, China; \\ 4. The Administrative Center for China's Agenda 21, Beijing 100038, China)
}

\begin{abstract}
Storm surges are a phenomenon of abnormal water- level rises under the influence of strong atmospheric turbulence in coastal areas and are effected by many factors, such as sea-level rise. China has seen frequent storm surges, especially in the southeastern coastal areas where their frequency is high and disaster losses are serious. This article systematically summarized the progress and main problems of storm surge research in China with regard to the hazard, vulnerability, and risk regionalization. Based on the characteristics and risk assessment of storm surges, the impact of climate change and adaptation strategies were further investigated. Especially in the context of climate change, future trend, recurrence periods, and high risk areas of storm surges would be greatly affected by sea-level rise. Thereby, a comprehensive risk assessment incorporating factors such as sea-level rise is urgently needed. Moreover, the changes in natural conditions and socioeconomic development in the coastal areas under global climate change should be taken into account to improve risk assessment with the combination of short-term and long-term views. In order to adapt to the risk of storm surge disasters under climate change, China has continuously improved the capacity building for emergency preparedness, structural defense, and policies and regulations to improve the ability of disaster prevention and mitigation.
\end{abstract}

Key words: climate change; storm surge; disaster impact; risk; adaptation; China 